\title{
EFEK GAMBIR (UNCARIA GAMBIR/HUNTER ROXB) TERHADAP AKTIVITAS LOKOMOTOR DAN NEUROKOGNITIF PADA TIKUS BETINA MODEL ALZHEIMER
}

\author{
GAMBIER (UNCARIA GAMBIR/HUNTER ROXB) ADMINISTRATION IMPROVES \\ LOCOMOTOR ACTIVITIES AND NEUROCOGNITIVE IMPAIRMENT IN \\ ALZHEIMER'S MODEL FEMALE RAT
}

Ulya Uti Fasrini, * Restu Susanti, ** Nur Indrawaty Lipoeto*

\begin{abstract}
Introduction: Locomotor activity (LA) disturbance and neurocognitive impairment in Alzheimer's disease (AD) mechanism was suggested through many ways; one of them is the induction of oxidative stress that corrupted hippocampus cortex.

Aims: The aim of this study was to determine whether or not the administration of potent antioxidant gambier catechin $(G D C)$ to AD model female rat improves locomotion (LA) and cognitive function (CF).

Methods: This experimental research was carried out to 12-week-old 25 Sprague dawley AD model female rats with proven CF impairment. Subjects were divided into 5 groups; control negative $(N)$ and positive (P), and catechin groups (AC1, AC2, and AC3), which treated with oral GDC, 20mg, 40mg, and 60mg/200gBW, respectively, for four weeks. LA (total arm entered) and spatial memory were measured before and after treatment using Y-maze based on spontaneous alternation of each groups.
\end{abstract}

Results: There were significant alteration differences in AC2 and AC3 groups (69\% and 2\%) after 40mg and $60 \mathrm{mg} / 299 \mathrm{gBW}$ treatment after 4 weeks.

Discussion: $40 \mathrm{mg}$ and $60 \mathrm{mg} / 200 \mathrm{gBW}$ oral GDC treatment for four weeks improves spatial memory function on AD model female rat, however no significant changes on locomotor activity.

Keywords: Alzheimer, catechin, cognitive, gambier, locomotor, rat

\section{ABSTRAK}

Pendahuluan: Gangguan aktivitas lokomotor dan penurunan neurokognitif pada penyakit Alzheimer diperkirakan terjadi melalui beberapa jalan, salah satunya stres oksidatif yang merusak korteks hipokampus.

Tujuan: Mengetahui efek pemberian antioksidan kuat katekin gambir (DKG) pada tikus betina model Alzheimer terhadap pergerakan (aktivitas lokomotor) dan fungsi kognitif.

Metode: Penelitian eksperimental terhadap 25 ekor tikus model Alzheimer Sprague dawley betina usia $12 \mathrm{minggu}$ yang sudah terbukti mengalami gangguan fungsi kognitif. Tikus dibagi menjadi 5 kelompok, yaitu kontrol negatif (N) dan positif (P), serta kelompok katekin (AC1, AC2, dan AC3) yang diberi DKG oral dengan dosis masing-masing 20mg, 40mg, dan $60 \mathrm{mg} / 200 \mathrm{gBB}$ selama empat minggu. Dilakukan penilaian uji lokomotor dan memori spasial menggunakan Y-maze pada awal dan setelah perlakuan berdasarkan perbedaan alternasi spontan dari setiap kelompok.

Hasil: Terdapat perbedaan alternasi yang signifikan pada kelompok AC2 dan AC3 (69\% dan 82\%) pascapemberian DKG oral 40mg dan $60 \mathrm{mg} / 200 \mathrm{gBB}$ selama empat minggu.

Diskusi: Pemberian DKG oral 40mg dan 60mg/200gBB selama empat minggu memperbaiki fungsi memori spasial pada tikus betina model Alzheimer, namun tidak bermakna pada aktivitas lokomotor.

Kata kunci: Alzheimer, gambir, katekin, kognitif, lokomotor, tikus

*Bagian Ilmu Gizi FK Universitas Andalas, Padang; **Bagian Neurologi FK Universitas Andalas, Padang. Koresponden: ulyaufi@ fk.unand.ac.id.

\section{PENDAHULUAN}

Stres oksidatif merupakan peristiwa biologis yang dikaitkan dengan gangguan neurokognitif, seperti penyakit Alzheimer. ${ }^{1-2}$ Secara global pada tahun 2015 terdapat hampir 50 juta orang yang menderita Alzheimer. ${ }^{3-5}$ Peningkatan insiden terutama terjadi pada dekade ketujuh atau kedelapan, meskipun pernah dilaporkan penderita Alzheimer dini pada usia dibawah 65 tahun. ${ }^{4}$ Indonesia diperkirakan mengalami peningkatan proporsi usia tua pada tahun 2020 sebesar 11,34\%. ${ }^{6}$ Dengan demikian, proporsi penderita Alzheimer juga akan meningkat, yaitu 
perempuan lebih tinggi daripada laki-laki. ${ }^{7-9}$

Alzheimer ditandai dengan penurunan kognitif yang progresif, dimulai dari kehilangan memori sampai keseluruhan fungsi intelektual yang melibatkan fungsi motorik, yang dapat berlanjut dan menyebabkan kematian. ${ }^{10}$ Alzheimer juga menimbulkan dampak terhadap ekonomi terkait pengeluaran kesehatan dan angka ketergantungan. Diperkirakan angka ketergantungan di Indonesia pada tahun 2020 sekitar 65\%, sedangkan di Sumatera Barat berkisar 60,22\%.

Gangguan neurokognitif yang terjadi pada Alzheimer diakibatkan oleh modifikasi protein tau pascatranslasi dan kaskade amiloid yang merupakan lanjutan dari stres oksidatif di otak. ${ }^{12-15}$ Perubahan profil lipid juga dikaitkan dengan stres oksidatif yang memengaruhi memori jangka pendek pada paruh baya. ${ }^{16}$ Katekin, dikenal sebagai antioksidan poten, diketahui mempunyai efek neuroprotektif terhadap Alzheimer. ${ }^{17}$ Katekin terdapat pada daun teh, anggur, dan gambir. Gambir, yang bila diekstraksi dengan cara yang tepat, dapat menghasilkan katekin murni sampai 96\%. Bahkan katekin yang dihasilkan dari gambir mempunyai aktivitas antioksidan yang tinggi. 18-19 Sumatera Barat merupakan penghasil gambir terbesar di dunia yang menyuplai 80\% kebutuhan dunia yang mungkin dapat berperan dalam memperbaiki gangguan pada Alzheimer. ${ }^{19}$

\section{TUJUAN}

Mengetahui efek katekin gambir (DKG) terhadap aktivitas lokomotor dan perbaikan kognitif pada Alzheimer menggunakan tikus model betina.

\section{METODE}

Penelitian eksperimen dengan rancangan post-treatment only yang dilakukan di Laboratorium Hewan Institut Pertanian Bogor (IPB). Semua prosedur eksperimen telah disetujui oleh Komite Etik Fakultas Kedokteran Universitas Andalas, Padang dan dilaksanakan sesuai dengan prosedur penelitian hewan yang berlaku di laboratorium. Semua aturan yang berlaku untuk keselamatan dan pemeliharaan hewan juga diperhatikan.

Alat dan bahan yang digunakan adalah kandang logam, timbangan digital, sonde, kapas, alkohol 5\%, stop watch, Y-maze, $\mathrm{NaCl}$ 0,9\% (fisiologis), serta katekin gambir yang ditimbang dan dilarutkan dalam $\mathrm{NaCl}$ fisiologis untuk mendapatkan konsentrasi yang diinginkan. Katekin dalam dosis berbeda (20, 40, dan $60 \mathrm{mg} / 200 \mathrm{gBB}$ ) diberikan secara oral menggunakan sonde.

Subjek menggunakan tikus Sprague dawley betina (150-160g) model Alzheimer usia 12 minggu yang diperoleh dari Laboratorium Hewan IPB yang dirumahkan pada kandang kawat (2 ekor perkandang). Lingkungan hewan dipertahankan sesuai standar laboratorium hewan, yaitu siklus gelap terang per 12 jam dan suhu ruangan berkisar $24-25^{\circ} \mathrm{C}$. Semua hewan mempunyai akses bebas ke makanan dan air. Tikus model telah menjalani uji kognitif menggunakan Y-maze dan terbukti mempunyai (\%) alternasi spontan kurang dari 50\%, yang menunjukkan telah terjadi gangguan kognitif yang jelas.

Sebanyak 25 tikus dibagi menjadi lima kelompok, yaitu $\mathrm{N}$ (kontrol negatif), $\mathrm{P}$ (kontrol positif), dan kelompok yang diberi DKG yaitu AC1, AC2, dan AC3 dengan dosis masing-masing 20, 40, dan $60 \mathrm{mg} / 200 \mathrm{gBB}$. Larutan katekin dibuat dengan melarutkan ekstrak DKG dalam bentuk bubuk dengan $\mathrm{NaCl}$ fisiologis agar diperoleh konsentrasi yang diinginkan. Pemberian DKG dilakukan setiap hari per oral menggunakan sonde lambung. Saat awal dan empat minggu sesudah pemberian katekin, dilakukan uji perilaku berupa aktivitas lokomotor dan memori spasial jangka pendek menggunakan Y-maze.

Y-maze merupakan suatu alat pengukuran fungsi kognitif untuk menilai keaktifan tikus dalam mengeksplorasi lingkungan yang baru. Alat ini berbentuk huruf $\mathrm{Y}$ yang terbuat dari plexiglass abu-abu. Tiap lengan yang membentuk sudut $120^{\circ}$, mempunyai panjang $35 \mathrm{~cm}$, lebar $5 \mathrm{~cm}$, dan tinggi $10 \mathrm{~cm}$ (Gambar 1). Lengan membentuk pusat triangular yang ekuilateral dengan area pada aksis terpanjang $15 \mathrm{~cm}$. Tikus biasanya lebih memilih bergerak menuju lengan yang baru dibandingkan kembali ke lengan yang sudah dilewatinya. Tes ini mampu menilai berbagai fungsi otak, terutama hipokampus, septum, basal forebrain, dan korteks prefrontal. ${ }^{20}$ 


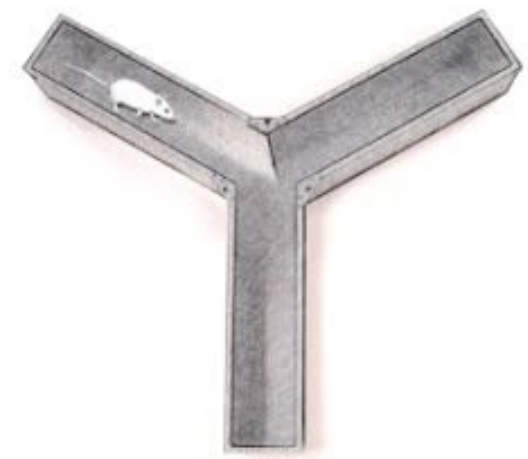

Gambar 1. Contoh Ilustrasi Y-maze dengan Tikus di dalamnya

Uji perilaku dilakukan pada ruangan tertutup dan tenang antara jam 7 dan 12 malam, menggunakan stop watch, yaitu semua tikus pada kelompok yang sama diuji pada hari yang sama. Untuk mengurangi kegelisahan pada hewan uji, lampu dinyalakan redup. Uji ini dilakukan selama 5 menit, yaitu tikus dibiarkan melakukan eksplorasi ketiga lengan Y-maze dengan bebas. Jika tikus memanjat dinding maze, maka akan langsung diturunkan ke lengan yang tertinggal. Lengan mulai tiap tikus berbeda untuk menghindari bias penempatan, ditandai dengan A, B, dan C. Antar sesi dilakukan pembersihan ketiga lengan Y-maze menggunakan alkohol 5\% dan dibiarkan kering.

Y-maze juga digunakan untuk menilai memori spasial. Jumlah masuk direkam dengan kamera video dan pilihan pertama dari lengan maze dicatat berdasarkan hasil rekaman. Hewan uji dinyatakan masuk ke lengan secara penuh bila ujung ekor tikus masuk keseluruhannya ke lengan yang dituju. Memori spasial dinyatakan dengan alternasi spontan $(\%){ }^{20}$ Alternasi dinyatakan berhasil bila hewan uji masuk ke tiga lengan berbeda secara berurutan, dihitung dari set triplet yang overlapping. Alternasi spontan (\%) ini dihitung sebagai rasio dari jumlah masuk yang benar terhadap kemungkinan alternasi spontan (jumlah masuk lengan total dikurangi dua). Misal lengan yang dimasuki tikus ABCABACA (8 lengan), maka kemungkinan alternasi spontan adalah $8-2=6$, sedangkan alternasi yang benar ada 4 (ABC-BCA-CAB-BAC), maka persentase alternasi spontan $=(4 / 6) \times 100=67 \%$.

Semua data perilaku dianalisis menggunakan statistik nonparametrik dengan SPSS 21. Uji t berpasangan digunakan untuk melihat perbedaan rerata sebelum dan setelah perlakuan. One way analysis of variance (Anova) digunakan untuk melihat perbedaan rerata aktivitas lokomotor dan memori spasial kelompok subjek, diikuti dengan uji post hoc (Games-Howell) untuk menentukan sumber efek yang signifikan. Perbedaan dinyatakan signifikan jika $\mathrm{p}<0,05$.

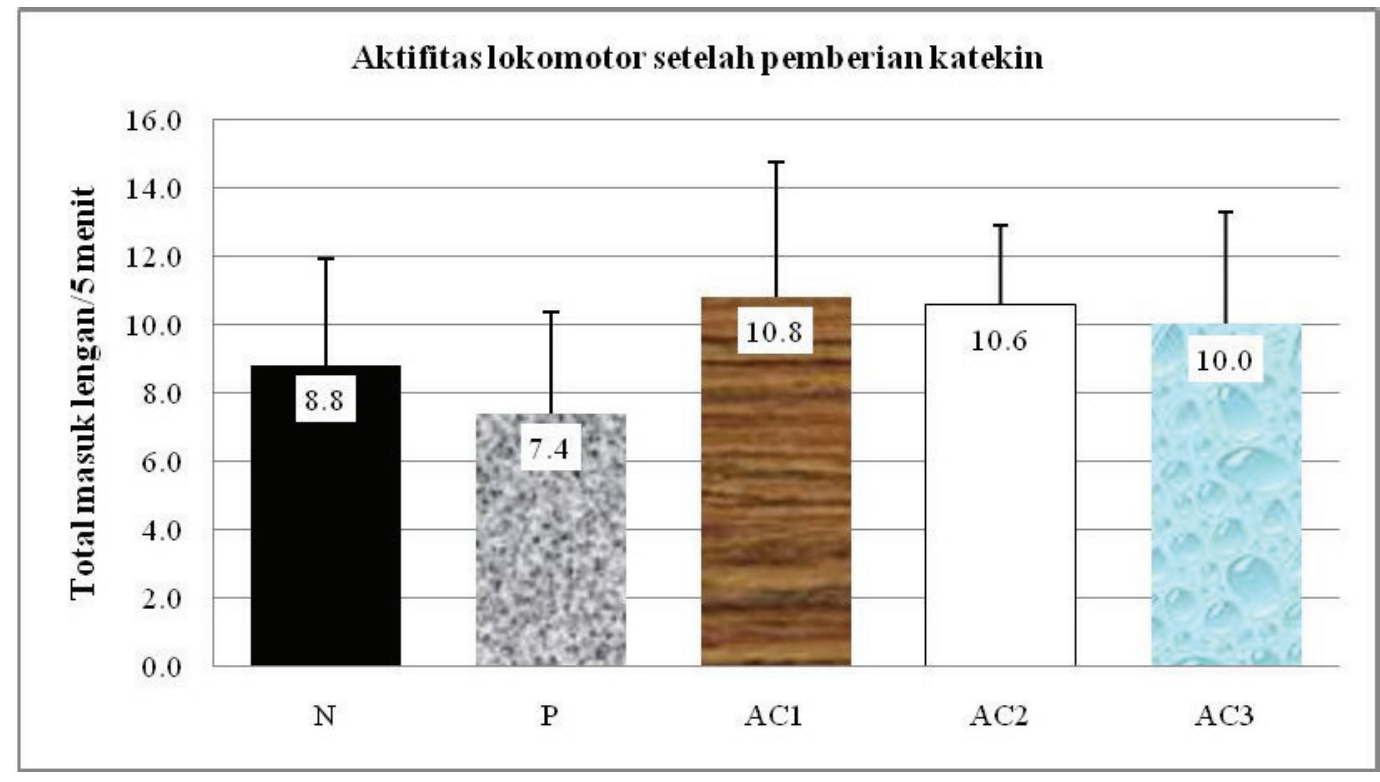

Gambar 2. Efek Pemberian DKG 20, 40, 60mg/200gBB terhadap Lokomotor selama 5 Menit Eksplorasi Y-maze $(\mathrm{n}=25)$

(Tiap balok mewakili rerata $\pm \mathrm{SD} ;{ }^{*} \mathrm{p}<0,05$ dibandingkan kontrol. N: kontrol negatif; P: kontrol positif; $\mathrm{AC} 1, \mathrm{AC} 2$, dan $\mathrm{AC} 3$ menerima dosis DKG masing-masing 20, 40, 60mg/200gBB). 


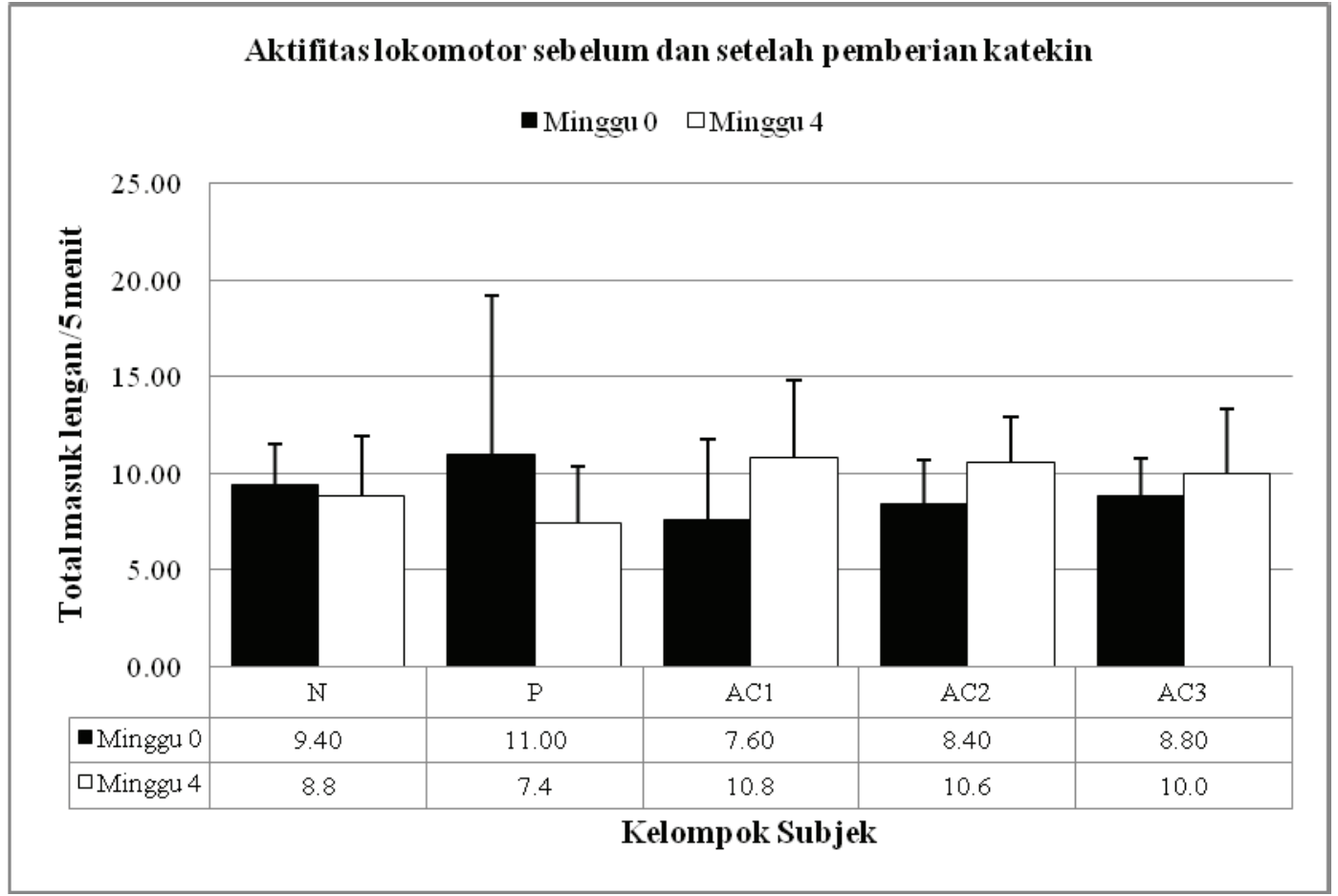

Gambar 3. Perbandingan Rerata Total Masuk Lengan dalam 5 Menit pada Y-maze setelah Pemberian DKG 20 , $40,60 \mathrm{mg} / 200 \mathrm{gBB}(\mathrm{n}=25)$

(Tiap balok mewakili rerata $\pm \mathrm{SD} ;{ }^{*} \mathrm{p}<0,05$ dibandingkan kontrol. N: kontrol negatif; P: kontrol positif; $\mathrm{AC} 1, \mathrm{AC} 2$, dan $\mathrm{AC} 3$ menerima dosis DKG masing-masing 20, 40, 60mg/200gBB).

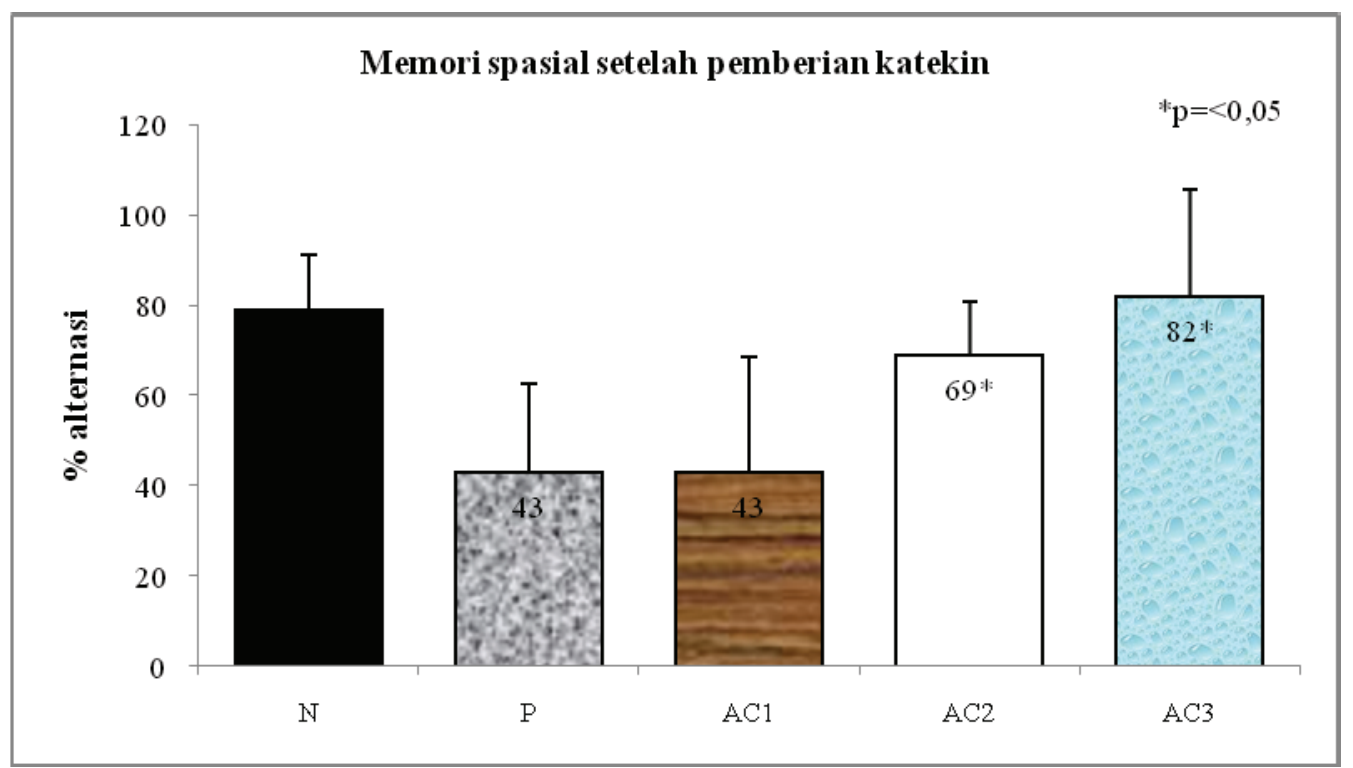

Gambar 4. Memori Spasial yang diukur dari Alternasi Spontan (\%) dalam 5 Menit pada Y-maze setelah Pemberian DKG 20, 40, 60mg/200gBB ( $\mathrm{n}=25)$.

(Tiap balok mewakili rerata $\pm \mathrm{SD} ;{ }^{*} \mathrm{p}<0,05$ dibandingkan kontrol N: kontrol negatif; P: kontrol positif; AC1, AC2 dan AC3 menerima dosis DKG masing-masing 20, 40, 60mg/200gBB).

\section{HASIL}

Gambar 2 menunjukkan aktivitas lokomotor di Y-maze selama 5 menit setelah pemberian DKG.
Terdapat peningkatan aktivitas lokomotor pada kelompok AC1 dan berangsur turun pada AC2 dan AC3. Penurunan ini berbanding terbalik dengan dosis 
yang diberikan. Pada Gambar 3 tidak didapatkan perbedaan aktivitas lokomotor yang bermakna sebelum dan setelah pemberian DKG 4 minggu menggunakan uji $t$ berpasangan $(p=0,504)$. Aktivitas lokomotor setelah pemberian DKG terlihat meningkat pada kelompok $\mathrm{AC} 1$ dengan kecenderungan menurun pada AC2 dan AC3. Dengan kata lain, terjadi penurunan aktivitas yang berbanding terbalik dengan dosis DKG yang diberikan. Demikian pula uji one way Anova tidak menunjukkan perbedaan rerata yang signifikan dari kelompok P dan AC1-AC3 ( $\mathrm{p}=0,422)$.
$60 \mathrm{mg} / 200 \mathrm{gBB}$.

\section{PEMBAHASAN}

Secara keseluruhan penelitian ini memperlihatkan perbaikan neurokognitif yang ditandai dengan membaiknya memori spasial dan aktivitas lokomotor. Area kunci untuk pembelajaran spasial dan memori adalah hipokampus dan korteks medial entorinal. ${ }^{21}$ Lesi dari area ini menyebabkan gangguan perilaku navigasi. Sel tempat (place cells) yang juga dikenal sebagai sel piramidalis di hipokampus akan teraktivasi oleh lokasi yang berbeda secara spesifik.

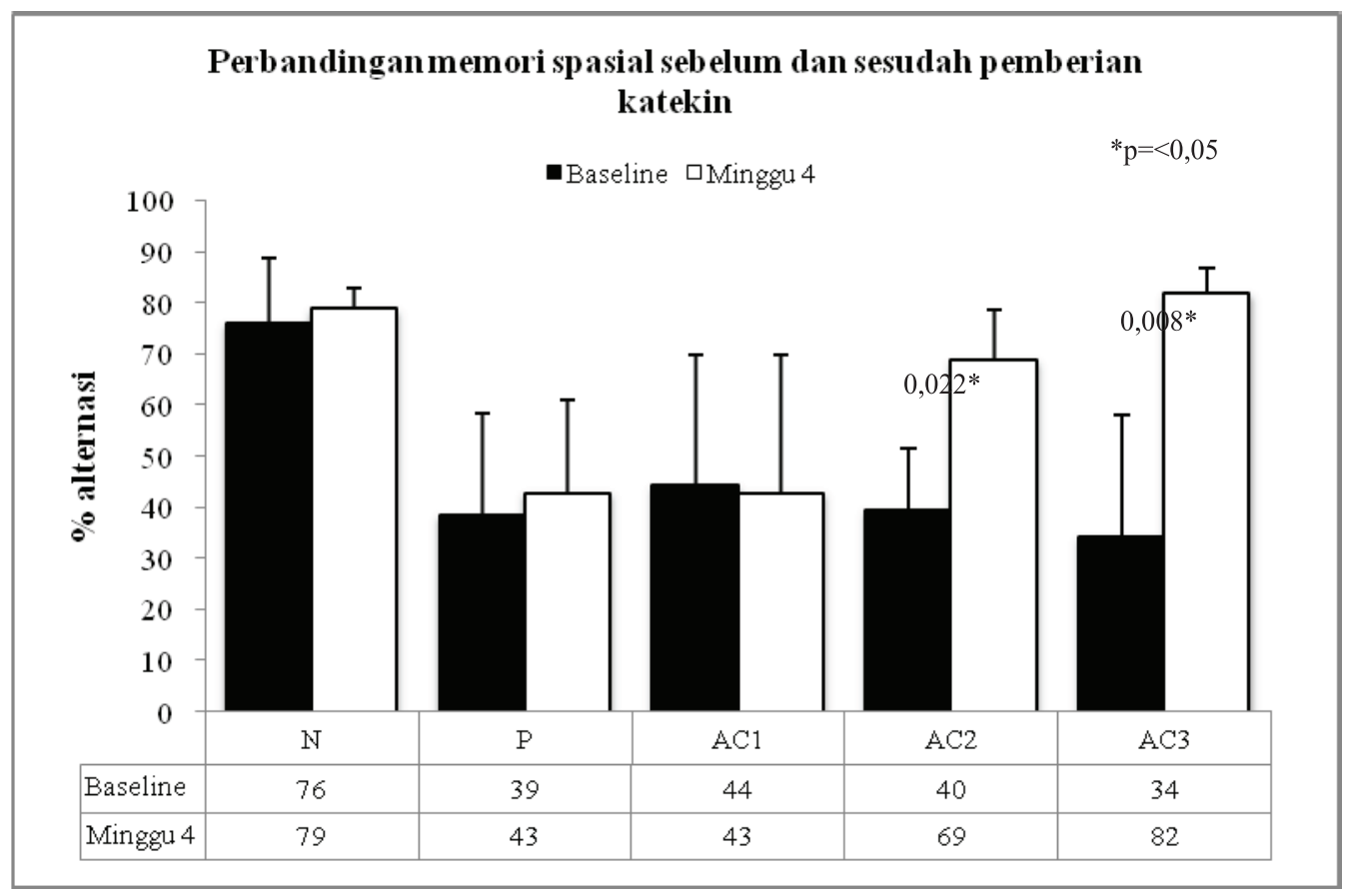

Gambar 5. Perbandingan Memori Spasial yang diukur dari Alternasi Spontan (\%) dalam 5 Menit pada Y-maze Setelah Pemberian DKG 20, 40, 60mg/200gBB $(\mathrm{n}=25)$

(Tiap balok mewakili rerata $\pm \mathrm{SD} ;{ }^{*} \mathrm{p}<0,05$ dibandingkan kontrol. $\mathrm{N}$ : kontrol negatif; P: kontrol positif; $\mathrm{AC} 1, \mathrm{AC} 2$, dan $\mathrm{AC} 3$ menerima dosis DKG masing-masing 20, 40, 60mg/200gBB).

Gambar 4 menunjukkan peningkatan memori spasial yang sejalan dengan peningkatan dosis DKG dibandingkan dengan kontrol negatif, terutama pada pemberian DKG 60mg/200gBB ( $\mathrm{p}=0,001)$. Adapun pada Gambar 5 tampak perbandingan memori spasial sebelum dan setelah pemberian DKG 4 minggu (20, $40,60 \mathrm{mg} / 200 \mathrm{gBB})$. Setelah diuji dengan one way Anova terdapat perbedaan rerata memori spasial dari kelompok kontrol positif dengan kelompok AC2 dan AC3 ( $\mathrm{p}=0,000)$ yang pasca-uji post hoc (GamesHowell) didapatkan $\mathrm{p}$ masing-masing 0,022 dan 0,008 . Perbedaan paling signifikan terlihat pada dosis
Selektifitas spasial yang terjadi memungkinkan tikus melakukan lokalisasi diri. ${ }^{21-23}$

Pada Alzheimer terjadi kerusakan pada hipokampus dan korteks entorinal yang muncul sebagai gangguan perilaku dan penurunan memori terutama memori spasial jangka pendek. Penelitian ini dimaksudkan untuk menilai kemungkinan efek perbaikan dari DKG dalam dosis yang berbeda terhadap tikus model Alzheimer. Tikus putih betina Sprague dawley dipilih karena merupakan tikus yang paling sering digunakan untuk penelitian yang berkaitan dengan uji efektivitas dan toksisitas suatu 
zat aktif dan untuk menilai perilaku dan fungsi kognitif. ${ }^{24-25}$

Penelitian ini memberikan hasil yang mendukung penelitian sebelumnya bahwa pemberian katekin dapat memperbaiki keadaan neurokognitif akibat penyakit Alzheimer. ${ }^{17-26}$ Penggunaan tiga dosis menunjukkan hasil linearitas efek atau dengan kata lain efek yang dihasilkan tergantung dengan besarnya dosis yang diberikan.

Tikus Alzheimer mempunyai aktivitas lokomotor yang berbeda dibandingkan normal. Pada penelitian ini meskipun terlihat peningkatan aktivitas pada kelompok yang diberi katekin $20 \mathrm{mg} / 200 \mathrm{gBB}$, aktivitas lokomotor pada subjek penelitian ini tidak menunjukkan perbedaan yang bermakna. Pergerakan tikus cenderung menurun mendekati kondisi sebelum pemberian DKG pada kelompok AC3. Namun penurunan aktivitas lokomotor ini terlihat sejalan dengan peningkatan dosis.

Fungsi kognitif dinilai dari alternasi spontan (\%) yang dilakukan oleh tikus. Alternasi ini menunjukkan kemampuan tikus mengenali daerah baru, yang merupakan bagian dari pembelajaran. Data yang ada menunjukkan perbaikan fungsi kognitif yang terlihat dari peningkatan persentase alternasi spontan dari semua kelompok yang mendapatkan katekin, terutama pada $\mathrm{AC} 3$ dengan alternasi spontan $82 \%(\mathrm{p}<0,05)$. Penelitian lain yang pernah dilaporkan menggunakan minuman dari ekstrak gambir terhadap mencit yang mengalami defisit kognitif juga menunjukkan perbaikan fungsi kognitif. ${ }^{27}$ Ejaz Ahmed dkk menunjukkan efek neuroprotektif katekin hidrat terhadap induksi streptozosin. Dengan demikian, katekin tidak hanya dapat digunakan untuk memperbaiki keadaan neurokognitif yang menurun akibat Alzheimer, tapi juga sebagai preventif, yaitu efek neuroprotektif sebagai aktivitas biologis dari antioksidan poten katekin. ${ }^{17,26-27}$

Keterbatasan penelitian ini antara lain pemodelan yang dilakukan tidak cukup lama untuk membuat tikus model mengalami gangguan motorik sebagai akibat lanjut dari kerusakan sel saraf pada Alzheimer. Oleh sebab itu, disarankan melakukan pemodelan lebih dari enam minggu untuk memastikan gangguan lokomotor juga sudah terjadi. Selain itu, tikus Sprague dawley mempunyai aktivitas yang rendah, sehingga perlu dipertimbangkan untuk menggunakan tikus lain yang lebih aktif, seperti tikus Long Evans.

\section{KESIMPULAN}

Pemberian katekin gambir dosis 40 dan $60 \mathrm{mg} / 200 \mathrm{gBB}$ selama 4 minggu dapat memperbaiki fungsi memori spasial yang menurun pada tikus betina model Alzheimer, namun tidak bermakna pada aktivitas lokomotor.

\section{UCAPAN TERIMA KASIH}

Penelitian ini dibiayai sebagian oleh Kementrian Riset dan Teknologi melalui Dana DI042. 01.02.400928/2016 tanggal 7 Desember 2015 dan berdasarkan surat perjanjian pelaksanaan penugasan penelitian Dosen pemula tahun anggaran 2016 78/ BBPT/PNP/FK-Unand-2016 tanggal 30 Agustus 2016.

\section{DAFTAR PUSTAKA}

1. World Health Organization. Dementia: a public health priority. Dementia; 2012. h. 1-112.

2. Alzheimer's Association. 2015 Alzheimer's disease facts and figures. Alzheimers Dement. 2015;11(3):332-84.

3. Reitz C, Brayne C, Mayeux R. Reviews epidemiology of alzheimer disease. Nat Publ Gr. 2011;7(3):1-16.

4. Mayeux R, Stern Y. Epidemiology of Alzheimer disease. Cold Spring Harb Perspect Med. 2012;2(8):119.

5. Prince M, Wimo A, Guerchet M, Gemma-Claire A, Wu YT, Prina M. World Alzheimer report 2015: the global impact of dementia - an analysis of prevalence, incidence, cost and trends. Alzheimer's Disease International; 2015.

6. Depkes RI. Info Datin Lansia. 2013 [diunduh 1 September 2015]. Tersedia dari: Pusdatin DepKes.

7. Kemkes RI. Pedoman Pelayanan Gizi Lansia. Pedoman Pelayanan Gizi Lansia; 2012.

8. Mielke MM, Vemuri P, Rocca WA. Clinical epidemiology of Alzheimer's disease: assessing sex and gender differences. Clin Epidemiol. 2014;6(1):37-48.

9. Purba JS. Peran inflamasi dan amiloid-beta pada patologi penyakit Alzheimer. Alzheimer. 2011;28(4): $1-9$.

10. Tejada-Vera B. Mortality from Alzheimer's disease in the United States: data for 2000 and 2010. NCHS Data Brief. 2013;(116):1-8.

11. Pusdatin Kemenkes RI. Gambaran kesehatan lanjut usia di Indonesia. Pusat Data dan Informasi Kementerian Kesehatan RI. 2013;(Semester 1):1-5. 
12. Mukaetova-Ladinska EBB, Harrington CRR, Roth M, Wischik CMM. Alterations in tau protein metabolism during normal aging. Dement Geriatr Cogn Disord. 1996;7(2):95-103.

13. Dong S, Duan Y, Hu Y, Zhao Z. Advances in the pathogenesis of Alzheimer's disease: a re-evaluation of amyloid cascade hypothesis. Transl Neurodegener. 2012;1(1): 18 .

14. Spires-Jones TL, Hyman B. The intersection of amyloid beta and tau at synapses in Alzheimer's disease. Neuron. 2014;82(4):756-71.

15. Naini SMA, Soussi-Yanicostas N. Tau hyperphosphorylation and oxidative stress, a critical vicious circle in neurodegenerative tauopathies? Oxid Med Cell Longev. 2015;2015:1-18.

16. Adhayani F, Listyaningrum D, Sjahrir H. Hubungan antara profil lipid dan gangguan memori pada usia paruh baya. Neurona. 2013;31(1):1-6.

17. Katergaris N, Dufficy L, Roach PD, Naumovski N. Green tea catechins as neuroprotective agents : systematic review of the literature in animal preclinical trials. Adv Food Technol Nutr Sci Open J. 2015;1(2):48-57.

18. Rahmawati N, Bakhtiar A, Putra P. Isolasi katekin dari gambir (uncaria gambir (hunter) roxb) untuk sediaan farmasi dan kosmetik. J Penelit Farm Indones. 2012;1(1):6-10.

19. Yeni G, Syamsu K, Suparno O, Mardliyati E, Muchtar H. Repeated extraction process of raw gambiers (uncaria gambier robx.) for the catechin production as an antioxidant. Int J Appl Eng Res. 2014;9(24):24565-78.
20. TSE Systems. TSE maze systems; multi-purpose learning \& memory testing systems for small laboratory animals. TSE System International Group; 2014. h. 1-15.

21. Pilly PK, Grossberg S. How do spatial learning and memory occur in the brain? Coordinated learning of entorhinal grid cells and hippocampal place cells. J Cogn Neurosci. 2012;24(5):1031-54.

22. Moser M-B, Moser EI. Functional differentiation in the hippocampus. Hippocampus. 1998;8:608-19.

23. Moser MB. Grid cells, place cells and memory: nobel lecture. The Nobel Prizes. Trondheim; 2014. h. 333 67.

24. Vorhees CV, Williams MT. Assessing spatial learning and memory in rodents. ILAR J. 2014;55(2):310-32.

25. Puzzo D, Gulisano W, Palmeri A, Arancio O. Rodent models for Alzheimer's disease drug discovery. Expert Opin Drug Discov. 2015;10(7):703-11.

26. Ahmed E, Khan MM, Javed H, Vaibhav K, Khan A, Tabassum R, dkk. Amelioration of cognitive impairment and neurodegeneration by catechin hydrate in rat model of streptozotocin-induced experimental dementia of Alzheimer's type. Neurochem Int. 2013;62(4):492-501.

27. Maryadhi N, Swastini D, Leliqia N. Pengaruh dosis minuman gambir terhadap peningkatan daya ingat mencit galur Balb/c. Portal Garuda. 2012;2012:55-8. 